DOI https://doi.org/10.18551/rjoas.2020-10.21

\title{
LOCAL ECONOMIC DEVELOP-MENT THROUGH STRENGTHENING THE TOURISM, AGRICULTURE AND PROCESSING INDUSTRY SECTORS IN WEST LOMBOK DISTRICT, INDONESIA
}

\author{
Amin M.* \\ Institute for Domestic Government, Indonesia \\ Baehaqi \\ Al Azhar Islamic University, Mataram, Indonesia \\ *E-mail: aminlombok77@gmail.com
}

\begin{abstract}
This study aims to analyze the potential of the tourism sector and the agricultural sector as well as the processing industry in West Lombok Regency and to formulate policy recommendations for the tourism and agriculture sectors as well as the processing industry. The results of this study indicate that local food business (farming and processing industry) in West Lombok district can produce and supply most of the types of food requested by hotels and restaurants. Hotels and restaurants, as well as suppliers that were met in this study did not know specifically whether these products were products from the West Lombok district, foreign products, or foreign products. Potential policy directions for strengthening business linkages in the tourism sector and agricultural businesses and managing local foodstuffs are: advocacy for the use of local food ingredients in hotel and restaurant food menus, increasing the number of tourist visits, increasing the competitiveness of local products in markets and purchasing centers for hotels and restaurants and suppliers, and access to finance for local producers and suppliers.
\end{abstract}

\section{KEY WORDS}

Tourism sector, agricultural sector, manufacturing, industry sector.

External forces such as globalization and technological advances have reduced the role of traditional economic sectors such as agriculture, forestry and mining as sources of livelihood for people in rural areas. This trend suggests the need for development policies and programs that pay special attention to providing greater employment and business opportunities outside the traditional sectors for rural populations. One of the non-traditional activities that are considered by many to have high potential for developing livelihood structures in many places in the world, including Indonesia and in West Lombok in particular, is tourism. In order for the welfare of the population in an inclusive manner, the growth and strengthening of linkages between tourism and local businesses needs to be emphasized. Local business referred to here is a business in the field of production which is mostly carried out by residents, such as: agriculture, food and industrial processing. A business relationship can be interpreted as a trade or business partnership.

The attractiveness of a tourism destination depends on its resource capacity. The main destination resources (primary) include: natural resources (climate, landscape, and ecosystem), cultural resources (cultural heritage, arts, archaeological values, traditions, scientific values, handicrafts, sub-cultural formations); and social resources (demographic characteristics, abilities, financial capital, knowledge, health-environment-property security systems, interests of local communities, etc.). Supporting destination resources (secondary) include: the accommodation sector (hotels, motels, beside the ground, housekeeping etc.), the catering sector (cafes, restaurants, etc.), the tour and travel sector, the transportation sector, the entertainment sector, the information sector, and the service sector.

In one of its studies, Arizona State University (2010) distinguishes tourism resources in an area into 8, namely: (i) historical regional development, (ii) place making and destination 
branding, (iii) tourism industry, (iv) public-infrastructure services dadn capital, (v) community governance (government), (vi) economic system, (vii) socio-cultural system, and (viii) natural and environmental systems. He explained, the relationship between these types of resources is as follows. Natural and environmental systems (land, water and air) as a foundation to support the social and cultural system and the economic system. The history of community (regional) development defines society as a place which is an important condition for image creation and destination branding. Social and cultural systems work together with community governance to provide public services, infrastructure and together with economic development to create capital. The tourism industry is supported in many ways by the other seven resources.

Society is an economic system that contains within its boundaries a number of resources are available to produce output, typically called welfare for its inhabitants. These resources include: political, social, economic and physical inputs that support or have the potential to support community decisions (Shafer, 1989). According to Aref \& Gill (2010), the dimensions of community capacity include, among others: leadership, participation, community structure, external support, expertise and knowledge, mobilization of community resources, and political power (to access and influence public policy).

Local facilities and local tourism resources in general form the basic foundation on which tourism experiences occur. This foundation is not as simple as regulating where tourist activities are carried out, but rather: it is an essential part of the tourist experience and the ultimate satisfaction of tourists (Herrero-Prieto \& Gomez-Vega, 2017).

The appropriate use of local resources affects the development of private enterprises and local economic development and growth. The appropriate combination of historical, cultural, environmental and managerial assets, as well as between public policy and private intervention influences the choice of destination through increasing the attractiveness of a tourist spot (Coccorese \& Pellecchia, 2006). Direct and indirect benefits to local communities are the result of this process (Denicolai, Cioccarelli, \& Zucchella, 2010).

The role of public policy making is crucial. On the one hand, it must create precedents in order to provide accessibility to tourism objects for tourists and avoid inefficiencies such as: transboundary use of local resources that threaten preservation and reduce the positive impact of tourism on local communities. On the other hand, public actors should reduce potential conflicts with the interests of private stakeholders who seek to maximize profits. Also, a good combination of public and private action can avoid underutilization of tourism resources and loss of potential demand (Dredge, 2006).

A review of several studies on local resources for tourism in Europe conducted by Scuderi (2018) found the following: the quality of cultural heritage and efficiency of destination management had a significant positive effect on the number of tourist visits. Cultural wealth alone is not sufficient to attract tourist arrivals in the long run due to competition between destinations. Besides the value of the benefits of cultural wealth, good tourism policies and coordination are important in order to make cultural attractiveness have a positive impact on tourist visits. This type of accommodation (self-catering) has a significant market share in many destinations, especially in areas where the role of the sharing economy (joint venture) is dominant in this type of accommodation: there is a demand for guests for additional intensive food services, and foreign tourists appreciate staff friendliness and quality. Wifi service. The calm atmosphere is only worth a benefit for tourists without children. Consumers do not consider furniture and utensils important. Innovation is also a source of tourism.

The factors that influence the attractiveness of international conferences, including: cultural offerings, knowledge intensity, and size are all influences. Becoming the host of international conferences can be an indication of the city as a cultural and technological center. Such specific factors need to be strengthened through the long-term policy of developing urban centers as places where knowledge is produced and diffused. In terms of efficiency, medium- scale accommodation companies are the most efficient, while smallscale companies show stagnant or decreasing efficiency developments. Age and location of the business have a negative relationship with efficiency performance. 


\section{METHODS OF RESEARCH}

Types of data to be collected in this study include primary data and secondary data. Primary data will be collected from research respondents, while secondary data will be collected from the Regional Statistics Book and related agencies. Data analysis was carried out using descriptive techniques. First, identifying the types of commodities (products) that can be supplied with local products (produced by farmers and processing industry players in the West Lombok district). This will be recognized by juxtaposing a hotel requisition list and a list of local (regional) production. Second, assessing the suitability of the quality and quantity of local products with hotel and restaurant procurement standards. Third, calculating the potential type, volume and value) of hotel and restaurant demand that can be supplied with local products.

\section{RESULTS OF STUDY}

This section will discuss the results of the study with the aim of: analyzing the potential for ties with the tourism business sector and the agricultural sector as well as the processing industry in West Lombok Regency, this potential is identified by analyzing the demand for hotel, cottage and restaurant tourism businesses for fresh and processed food ingredients.

Table 1 - Respondents' Business Profile

\begin{tabular}{|c|c|c|c|c|c|c|}
\hline No & Aspect & Parameter & Star Hotel & Budget Hotel & Cottage & Restaurant \\
\hline 1 & Number of respondents & - & 6 & 4 & 5 & 6 \\
\hline \multirow{3}{*}{2} & \multirow{3}{*}{ Management level (\%) } & Main & 50,00 & 50,00 & 80,00 & 83,33 \\
\hline & & Branch & 16,67 & 25,00 & 20,00 & 16,67 \\
\hline & & Unit & 33,33 & 25,00 & 0,00 & 0,00 \\
\hline \multirow{3}{*}{3} & \multirow{3}{*}{ Length of operation (years) } & Mean & 23,33 & 3,25 & 8,80 & 19,50 \\
\hline & & Median & 23,50 & 2,00 & 4,00 & 18,00 \\
\hline & & Min-Max & $16-32$ & $1-8$ & $1-33$ & 13-33 \\
\hline \multirow{3}{*}{4} & \multirow{3}{*}{ Number of rooms (rooms) } & Mean & 114,50 & 25,00 & 10,00 & $\mathrm{Na}$ \\
\hline & & Median & 110,50 & 21,00 & 12,00 & $\mathrm{Na}$ \\
\hline & & Min-Max & $50-178$ & $10-48$ & $3-15$ & $\mathrm{Na}$ \\
\hline \multirow{3}{*}{5} & \multirow{3}{*}{ Number of rsto seats (seats) } & Mean & 161,17 & 33,25 & 25,00 & 77 \\
\hline & & Median & 175,00 & 34,00 & 16,00 & 75 \\
\hline & & Min-Max & $50-257$ & $20-45$ & $0-85$ & $40-102$ \\
\hline \multirow{3}{*}{6} & \multirow{3}{*}{ Low season room occupation (\%) } & Mean & 26,50 & 17,75 & 23,00 & $\mathrm{Na}$ \\
\hline & & Median & 25,00 & 18,50 & 20,00 & $\mathrm{Na}$ \\
\hline & & Min-Max & $5-54$ & $4-30$ & $5-40$ & $\mathrm{Na}$ \\
\hline \multirow{3}{*}{7} & \multirow{3}{*}{ High season room occupation (\%) } & Mean & 85,00 & 57,50 & 72,20 & $\mathrm{Na}$ \\
\hline & & Median & 87,50 & 55,00 & 60,00 & $\mathrm{Na}$ \\
\hline & & Min-Max & $65-100$ & $20-90$ & $56-95$ & $\mathrm{Na}$ \\
\hline \multirow{3}{*}{8} & \multirow{3}{*}{ Low season seat occupation (\%) } & Mean & 25,83 & 14,75 & 21,67 & 12,50 \\
\hline & & Median & 25,00 & 12,50 & 20,00 & 7,50 \\
\hline & & Min-Max & $5-50$ & $4-30$ & $5-40$ & $5-30$ \\
\hline \multirow{3}{*}{9} & \multirow{3}{*}{ High season seat occupation (\%) } & Mean & 85,00 & 55,00 & 70,33 & 65,00 \\
\hline & & Median & 87,50 & 55,00 & 60,00 & 62,50 \\
\hline & & Min-Max & $65-100$ & $20-90$ & $56-95$ & $50-80$ \\
\hline \multirow{3}{*}{10} & \multirow{3}{*}{ Number of low season guests (person / day) } & Mean & 32,22 & 5,25 & 2,74 & 9,64 \\
\hline & & Median & 38,86 & 5,20 & 2,40 & 6,30 \\
\hline & & Min-Max & $3,20-57,20$ & $1,00-9,60$ & $1,00-5,20$ & $3,50-30,00$ \\
\hline \multirow{3}{*}{11} & \multirow{3}{*}{ Number of guests in high season (person / day) } & Mean & 94,47 & 13,85 & 7,31 & 50,58 \\
\hline & & Median & 84,25 & 10,75 & 7,20 & 50,63 \\
\hline & & Min-Max & $50-178$ & $5,10-28,80$ & $1,68-12,35$ & $26-80$ \\
\hline
\end{tabular}

Source: Primary Data.

Note: the number of hotel guests is calculated by transferring the occupation level and the number of rooms available at each hotel: while the number of restaurant guests is calculated by transferring the occupancy rate and the number of seats available at each restaurant. The assumption used is that the number of hotel guests is determined by the number of rooms available (not the number of hotel restaurant seats available), and the number of restaurant guests is determined by the number of seats available.

Most of the respondents are the main office; the level of business management of the respondents is divided into three, namely: the main office, branch offices and business units. Based on this classification, the dominant level of management is the main office: $50 \%, 50 \%$ 
$80 \%$ and $83.33 \%$ of the number of respondents for star hotels, jasmine hotels, tourist lodges, and restaurants. The average operational rate of star hotels, jasmine hotels, tourist huts and restaurants is 23 years, 3 years, 9 years and 20 years.

The number of star hotel rooms tends to be more than the number of jasmine hotel rooms and tourist cottages. Consecutively, the average number of rooms for star hotels, jasmine hotels, and tourist lodges is 115 rooms, 25 rooms, and 10 rooms.

The number of restaurant seats is also the largest in star hotels, followed by restaurants, budget hotels and tourist lodges. It is interesting to note here that hotels generally also provide restaurants in addition to providing rooms, while restaurants generally do not provide rooms. Successively, the average number of restaurant seats for star hotels, budget hotels; tourist lodges, and restaurants are 161,33,25, and 77.

The room occupancy rate and available restaurant chairs are higher in high season and low season. In general, the low season is in January - May while the high season is in July December. In the low season, room occupancy rates are $26.50 \%$ for jasmine hotels, and $72.20 \%$ for tourist cottages. Restaurants in the low season are an average of $25.83 \%$, $14.75 \%, 21.67 \%$ and $12.50 \%$ for star hotels, jasmine hotels, tourist lodges and restaurants, respectively while the occupation of restaurant chairs in the high season is an average of $85 \%, 55 \%, 70.33 \%$, and $65 \%$ for star hotels, jasmine hotels, tourist lodges, and restaurants, respectively.

The number of hotel and restaurant guests in the low season is between $1 / 3$ to $1 / 2$ of the number of hotel and restaurant guests during the high season. The number of guests of star hotels, jasmine hotels, tourist lodges and restaurants in the low season is an average of 32 people, 5 people, 3 people and 10 people per day, while the number of guests during the high season is an average of 94 people, 7 people, and 51 people per day.

The food procurement system for tourism business in the study area is divided into two, namely: procurement through supplier supply and procurement through direct purchases in the market. The market in this area is the traditional kebon roek market and retail shops, the kebon roek market is for the purchase of fresh foodstuffs, while the retail shop is a shop for purchasing other food items, such as: rice, ground coffee, sugar, bottled water and others. The distribution of respondents according to the procurement system is given in Table 2 .

The food procurement system used tends to be different, according to the business category and the type of food purchased by the respondent. The procurement system through suppliers dominates the procurement of all types of foodstuffs at star hotels, while the direct purchase system in the local market dominates the procurement of foodstuffs at tourist lodges and restaurants, except for processed food. both procurement systems are equally important in jasmine hotels. Unlike the procurement system for other categories / types of foodstuffs, the procurement system through suppliers is dominant for processed food ingredients.

Table 2 - Percentage Distribution of Total Respondents by Procurement System

\begin{tabular}{|c|c|c|c|c|c|c|c|c|c|}
\hline \multirow{2}{*}{ No } & \multirow{2}{*}{ Type of food } & \multicolumn{2}{|c|}{ Star hotel } & \multicolumn{2}{c|}{ Budget hotel } & \multicolumn{2}{c|}{ Cottage } & \multicolumn{2}{c|}{ Restaurant } \\
\cline { 3 - 10 } & Supplier & Market & Supplier & Market & Supplier & Market & Supplier & Market \\
\hline 1 & Fresh vegetables & 83 & 16 & 50 & 50 & 20 & 80 & 50 & 50 \\
\hline 2 & Fresh fruit & 83 & 16 & 50 & 50 & 0 & 100 & 50 & 50 \\
\hline 3 & Fresh fish & 67 & 33 & 50 & 50 & 20 & 80 & 33 & 67 \\
\hline 4 & Fresh meat & 83 & 17 & 50 & 50 & 50 & 50 & 33 & 67 \\
\hline 5 & Processed materials & 100 & 0 & na & Na & na & Na & 100 & 0 \\
\hline 6 & Other foodstuffs & 83 & 17 & 50 & 50 & 20 & 80 & 50 & 50 \\
\hline
\end{tabular}

Source: Primary Data.

The area of origin of the fresh and processed food products requested by the respondent cannot be known with certainty. Although it can roughly be distinguished between local and non-local products, it cannot be ascertained where the products were produced. For example, apples and peers are known to be imported products but it is not known where the place of production is. Pineapples, bananas, papayas, several types of vegetables and even grapes are known to be produced in the West Lombok regency, but we 
cannot know for sure where the products purchased by hotels and restaurants are not known. Respondents can only provide information about the place where they purchased it. Several suppliers that were met during the field study were also uncertain about the places where the vegetables were produced.

Fresh vegetables requested by respondents included 22 types of vegetables, namely: lettuce, kale, carrots, potatoes, broccoli, mustard greens, spinach, tomatoes, chilies, green beans, peppers, cucumbers, eggplant, cabbage, flower vegetables, onions, zukini, beans. Long, baby corn, onion spirin, and masrum. Table 3 presents the number and value of respondents' requests for these types of vegetables. Only some of the types of vegetables requested by hotels and restaurants are commonly produced in West Lombok Regency, such as: kale, flower vegetables, string beans, chilies, tomatoes, cucumbers, eggplant, and masrum. Other types are thought to come from other regions, or even be imported products.

Table 3 - Number and Value of Respondents' Requests for Hotels and Restaurants for Various Types of Fresh Vegetables

\begin{tabular}{|c|c|c|c|c|c|c|c|}
\hline \multirow{2}{*}{ No } & \multirow{2}{*}{ Jenis } & \multirow{2}{*}{$N$} & \multicolumn{3}{|c|}{ Number of purchases per month } & \multicolumn{2}{|c|}{ Purchase value per month } \\
\hline & & & Quiet & Crowded & Unit & Lonely (Rp) & Crowded (Rp) \\
\hline 1 & Selada & 13 & 169 & 428 & $\mathrm{~kg}$ & 6.383 .000 & 16.165 .231 \\
\hline 2 & Kangkung & 12 & 112 & 266 & $\mathrm{~kg}$ & 1.162 .000 & 2.759 .750 \\
\hline 3 & Wortel & 19 & 433 & 1.115 & $\mathrm{~kg}$ & 8.295 .368 & 21.361 .053 \\
\hline 4 & Kentang & 14 & 1.032 & 2.086 & $\mathrm{~kg}$ & 19.018 .286 & 38.442 .000 \\
\hline 5 & Brokoli & 4 & 33 & 80 & $\mathrm{~kg}$ & 1.155 .000 & 2.800 .000 \\
\hline 6 & Sawi & 14 & 162 & 599 & $\mathrm{~kg}$ & 1.876 .886 & 6.933 .600 \\
\hline 7 & Tauge & 6 & 113 & 171 & $\mathrm{~kg}$ & 1.130 .000 & 1.710 .000 \\
\hline 8 & Bayam & 4 & 235 & 712 & ikat & 317.250 & 961.200 \\
\hline 9 & Tomat & 9 & 210 & 609 & $\mathrm{~kg}$ & 2.940 .000 & 8.526 .000 \\
\hline 10 & Cabe & 4 & 70 & 244 & $\mathrm{~kg}$ & 2.342 .083 & 8.163 .833 \\
\hline 11 & Buncis & 10 & 119 & 394 & $\mathrm{~kg}$ & 1.725 .500 & 5.713 .000 \\
\hline 12 & Paprika & 7 & 88 & 204 & $\mathrm{~kg}$ & 4.714 .286 & 10.928 .571 \\
\hline 13 & Timun & 5 & 16 & 55 & $\mathrm{~kg}$ & 80.000 & 276.000 \\
\hline 14 & Terong & 2 & 6 & 20 & $\mathrm{~kg}$ & 45.000 & 150.000 \\
\hline 15 & Kol & 14 & 170 & 814 & $\mathrm{~kg}$ & 1.627 .143 & 7.791 .143 \\
\hline 16 & Sayur kembang & 7 & 39 & 99 & $\mathrm{~kg}$ & 957.000 & 2.460 .857 \\
\hline 17 & Bawang & 4 & 86 & 216 & $\mathrm{~kg}$ & 2.010 .250 & 5.049 .000 \\
\hline 18 & Zukini & 1 & 1 & 4 & $\mathrm{~kg}$ & 45.000 & 180.000 \\
\hline 19 & Kacang panjang & 3 & 15 & 53 & $\mathrm{~kg}$ & 205.000 & 724.333 \\
\hline 20 & Baby corn & 2 & 6 & 17 & $\mathrm{~kg}$ & 180.000 & 510.000 \\
\hline 21 & Onion spring & 1 & 48 & 81 & $\mathrm{~kg}$ & 1.344 .000 & 2.268 .000 \\
\hline 22 & Masrum & 1 & 15 & 25 & paket & 330.000 & 550.000 \\
\hline
\end{tabular}

Source: Primary Data.

Judging from the number of respondents who asked, popular types of vegetables were carrots, potatoes, cabbage, lettuce, mustard greens, kale, and beans. Ten or more respondents asked for these types of vegetables. Meanwhile, only 9 or fewer respondents requested other types of vegetables (Table 3). With the exception of carrots and ketang, these popular types of vegetables are estimated to be produced in the West Lombok district, so they have the potential to develop. The next question is which types of vegetables have market competitiveness and are business-worthy to be produced by farmers.

Relatively high demand is defined as a type of vegetable with the number of respondents requesting $100 \mathrm{~kg}$ or more per month during the low season. The types of vegetables included in this category are lettuce, kale, carrots, potatoes, mustard greens, bean sprouts, spinach, tomatoes, green beans and cabbage. Vegetables with relatively high demand are lettuce, carrots, potatoes, tomatoes, chilies, peppers and onions.

The type and quantity of fresh meat requested by hotels and restaurants varies between business categories. This is indicated by the type of fresh meat in the diatsas respondent's request, star hotels ask for 9 types and dominate the number of requests for 6 types of meat, namely: beef, chicken, chicken brest, chicken wings, beef mince, and beet bone. Hotel Melarti asked for 4 types of meat to dominate the number of requests for 1 type of meat, namely: beet fillets. The tourist lodge asked for as many as 5 kinds of fresh meat but none dominated the number of requests. The restaurant asks for 9 types and dominates the 
number of requests for 4 types, namely: chicken fillet, lamb / goat, duck, and chicken leg. The variation in demand between these business categories is estimated as a result of differences in preferences (types of meat) and differences in business scale (number of rooms / chairs).

Table 4 - Number and Value of Respondents' Requests for Hotels and Restaurants for Various Types of Fresh Meat

\begin{tabular}{|c|c|c|c|c|c|c|c|}
\hline \multirow{2}{*}{ No } & \multirow{2}{*}{ Jenis } & \multicolumn{3}{|c|}{ Number of purchases per month } & \multicolumn{2}{c|}{ Purchase value per month } \\
\cline { 4 - 8 } & & Quiet & Crowded & Unit & Lonely (Rp) & Crowded (Rp) \\
\hline 1 & Beef & 16 & 309 & 855 & $\mathrm{~kg}$ & 35.236 .484 & 97.657 .031 \\
\hline 2 & Chicken & 10 & 694 & 1.498 & $\mathrm{~kg}$ & 25.192 .200 & 54.359 .250 \\
\hline 3 & Beef filet & 3 & 14 & 26 & $\mathrm{~kg}$ & 1.586 .667 & 2.890 .000 \\
\hline 4 & Chicken filef & 4 & 45 & 134 & $\mathrm{~kg}$ & 2.700 .000 & 8.010 .000 \\
\hline 5 & Domba/kambing & 3 & 25 & 80 & $\mathrm{~kg}$ & 6.541 .667 & 20.933 .333 \\
\hline 6 & Bebek & 2 & 62 & 156 & $\mathrm{~kg}$ & 10.230 .000 & 25.740 .000 \\
\hline 7 & Chicken leg & 3 & 70 & 330 & $\mathrm{~kg}$ & 2.753 .333 & 12.980 .000 \\
\hline 8 & Chicken brest & 1 & 30 & 150 & $\mathrm{~kg}$ & 1.650 .000 & 8.250 .000 \\
\hline 9 & Chicken wing & 2 & 111 & 349 & $\mathrm{~kg}$ & 2.386 .500 & 7.503 .500 \\
\hline 10 & Beef mince & 2 & 5 & 58 & $\mathrm{~kg}$ & 375.000 & 4.350 .000 \\
\hline 11 & Beef bone & 1 & 1 & 6 & $\mathrm{~kg}$ & 60.000 & 360.000 \\
\hline
\end{tabular}

Source: Primary Data.

Table 5 - Number and Value of Respondents' Requests for Hotels and Restaurants for Various Types of Processed Food Materials

\begin{tabular}{|c|c|c|c|c|c|c|c|}
\hline \multirow{2}{*}{ NO } & \multirow{2}{*}{ Jenis } & \multicolumn{3}{|c|}{ Number of purchases per month } & \multicolumn{2}{c|}{ Purchase value per month } \\
\cline { 4 - 8 } & & Quiet & Crowded & Unit & Lonely (Rp) & Crowded (Rp) \\
\hline 1 & Kentang siap goreng & 1 & 6 & 20 & $\mathrm{~kg}$ & 210.00 & 700.000 \\
\hline 2 & Salami & 2 & 6 & 14 & $\mathrm{~kg}$ & 723.250 & 1.841 .000 \\
\hline 3 & Beef-ham & 3 & 5 & 15 & $\mathrm{~kg}$ & 624.600 & 1.735 .000 \\
\hline 4 & Chicken ham & 1 & 1 & 5 & $\mathrm{~kg}$ & 60.000 & 225.000 \\
\hline 5 & Beef-baccon & 2 & 10 & 12 & $\mathrm{~kg}$ & 1.480 .000 & 1.702 .000 \\
\hline 6 & Beef meatball & 1 & 5 & 12 & $\mathrm{~kg}$ & 350.000 & 840.000 \\
\hline 7 & Beef-sausage & 2 & 3 & 17 & $\mathrm{~kg}$ & 230.400 & 1.188 .000 \\
\hline 8 & Chicken-sausage & 1 & 24 & 90 & $\mathrm{~kg}$ & 960.000 & 3.600 .000 \\
\hline 9 & Icecream & 1 & 2 & 4 & $\mathrm{Itr}$ & 58.000 & 116.000 \\
\hline 10 & Sstring & 1 & 4 & 20 & $\mathrm{Kg}$ & 144.000 & 720.000 \\
\hline 11 & cococruch & 1 & 10 & 37 & Kotak & 394.000 & 1.457 .800 \\
\hline 12 & Honeystarch & 1 & 5 & 19 & kotak & 199.250 & 757.150 \\
\hline
\end{tabular}

Source: Primary Data.

Demand for processed food is only made by star hotels and restaurants. This is indicated by the distribution of the average percentage of respondents' requests according to business categories, jasmine hotels and tourist lodges do not have demand for processed food ingredients. Star hotels request 9 out of a total of 12 types of processed foodstuffs requested by hotels and restaurants, namely: salami, beef ham, chicken ham, beet bacon, chicken sausage, icecream, shoestrings cococrunch, and honey starch. Meanwhile, the restaurant asks for only 6 types, namely: ready-to-fry potatoes, salami, beet ham, beet bacon, beat meatball, and beet sausage.

Star hotels dominate most of the types of processed food requested by hotels and restaurants. This shows that star hotels dominate the demand for the 9 types of processed food they request, while restaurants dominate only 3 of the 6 types that are requested, namely ready- to-fry beef meatball and beef sausage.

\section{DISCUSSION OF RESULTS}

This section discusses the results of the study with regard to the purpose of formulating policy recommendations for strengthening tourism sector business, fresh and processed agricultural food business and processing industries in West Lombok Regency.

The number of visitors is the main factor determining the demand for hotels and restaurants for food. Hotel and restaurant demand for food is determined according to the number of visitors. Hotels and restaurants differ between the low season and the high 
season. As the destinations in section 4.1.9; the average number of visitors to star hotels, jasmine hotels, tourist lodges and restaurants during the low season is 32 people, 5 people, 3 people, and 10 people per day; and is 59 people, 14 people, 7 people and 41 people during high season. Besides the seasonal increase in the number of visitors is also very vulnerable to the risk of safety, the number of visitors is reported to have decreased drastically as a result of the earthquake that hit Lombok in the second semester of 2018.

The types and amounts of foodstuffs requested by hotels and stores vary according to business category. As explained in each business category the tourism sector (star hotels, jasmine hotels, tourist lodges and restaurants) has a tendency towards the type of food purchased and the procurement system used. Star hotels and restaurants have a higher number of requests than jasmine hotels, and tourist lodges for most types of foodstuffs this is due to the difference in scale of business, represented by the number of rooms for hotels and the number of corrections for restaurants.

Hotel and restaurant demand for food is decided by two main actors, namely: chef and the procurement department. This is explained by the following general procedures for hotel and restaurant foodstuff procurement: first the chef determines the type and amount of food needed according to the number of visitors and food menu preferences, and then, according to the type and quantity of these needs, the Procurement Department decides the procurement system. What hotels and restaurants use can be divided into two, namely: the procurement system through suppliers and through the market? Star hotels tend to use a more procurement system through suppliers rather than through the market for all types of foodstuffs. On the other hand, tourism trends tend to use a procurement system through the market, except for the type of fresh meat food ingredients. Meanwhile, jasmine hotels use both procurement systems in a balanced manner, but use a supplier system for foodstuffs. Restaurants tend to use a market system for fresh fish and meat, and a combination of suppliers and markets for fresh vegetables, fresh fruit, and other ingredients.

Technically, local food business (farming and processing industry) in West Lombok district can produce and supply most of the types of food requested by hotels and restaurants. Hotels and restaurants, as well as suppliers that were met in this study did not know specifically whether these products were products from the West Lombok district, foreign products, or foreign products. However, most of these types of food can technically be produced in the West Lombok district. The market competitiveness of local products is a key prerequisite for realizing the potential for strengthening linkages in the tourism sector and food business in West Lombok district. Hotels and restaurants realize their demand for food through direct purchases on the market or through purchases (orders) through suppliers. Meanwhile, the supplier in question is a business entity supplying foodstuffs to hotels and restaurants. Most hotels and restaurants shop at the Kebon Roek Traditional Market (Ampenan) for fresh food items (vegetables, fruit, fish and meat), and at the Foodstuff Stores (Cakranegara) for rice, sugar, coffee, milk, bottled water, and other foodstuffs. Most of the suppliers also shop at traditional markets and grocery stores to fulfill orders for hotel and restaurant partners. Therefore, food products in West Lombok Regency must be superior in terms of quality and price compared to products from other regions to win the competition against hotel and restaurant demand at the Kebon Roek traditional market and at the main foodstores in Cakranegara. However, based on the assessment of hotel and restaurant suppliers found in this study, local food producers tend to focus more on general public demand rather than the demand for the tourism sector. This is because the demand for hotels and restaurants is relatively small compared to general market demand, and is dynamic depending on the season of visit. According to hotels, restaurants and suppliers found in this study, food products offered in the market are generally not standardized, marked with one price for all qualities. This does not give the producer the correct incentives to improve the quality of the output. Producers with low-quality produce get the same prices as producers with medium or high-quality produce. On the other hand, buyers who are lucky (or knowingly choose) obtain a high quality product by paying the same price as the buyer for obtaining a lower quality product.

Small and micro-scale local food producers face constraints on capital adequacy to be 
able to take on the role of a supplier of star hotels and restaurants and relatively large restaurants tend to make purchases through suppliers whose payments are monthly. This means that new suppliers receive payment after delivering the goods ordered by partner hotels and restaurants, within a month or between 7 and 15 times. As a consequence, suppliers must have sufficient operating capital to cover the costs of all goods ordered by partner hotels and restaurants in a month. Apart from the relatively large operating capital, suppliers also need fixed capital, such as: refrigeration machines, packing facilities and transportation. Access to appropriate financial services has the potential to solve the problem of capital adequacy for suppliers (above). The feature of financial services as intended is that it allows suppliers to get payment every time a delivery of goods is ordered by partner hotels and restaurants. For this, as an imermediator, financial institutions make payments on behalf of partner hotels and restaurants in accordance with the receipt of goods from the hotel and restaurant. Intermediation service fees can be borne jointly or by one of the parties (suppliers and / or partner hotels and restaurants). Supplying demand for small-scale hotels and restaurants is not business feasible for suppliers or for local food producers, so some hotels and restaurants have to make purchases directly on the market.

Processing industry in West Lombok Regency Advocacy for the use of local food ingredients in hotel and restaurant food menus. The higher the content of local food ingredients in the food menu served by hotels and restaurants, the higher the demand for local foodstuffs. Among the potential programs / activities for this purpose are the innovation of food design for hotels and restaurants made from local food, and the introduction of food made from local food into the chef education and training curriculum. Increased number of tourist visits. This will increase the number of guests at hotels and restaurants, which in turn will increase their demand for local food products. Among the potential activity programs to increase the number of tourist visits are: development of tourist attractions and experiences to increase the attractiveness of destinations, tourism service standards that increase consumer satisfaction, culinary tourism, and digital platform-based tourism promotion schemes. Increased competitiveness of local products in the market and purchasing centers for hotels and restaurants and suppliers. Among the potential program activities for this purpose are: the introduction of appropriate and cost- effective cultivation technology, development of production centers for the types of foodstuffs requested by hotels and restaurants, standardization of quality and safety of local food products, and supply chain management of types of ingredients. Among the potential program activities for this purpose are: development of links between banks, suppliers and hotel restaurants, and access to People's Business Credit (KUR).

\section{CONCLUSION}

The potential for business links in the tourism and agriculture sectors as well as the local processing industry, as shown by hotel and restaurant demand for vegetables, fruit, fish, meat, processed foodstuffs and other foodstuffs are as follows:

Fresh vegetables, including 22 types of vegetables, namely: lettuce, kale, carrots, potatoes, broccoli, mustard greens, bean sprouts, spinach, tomatoes, chilies, green beans, peppers, cucumbers, eggplant, cabbage, vegetable flowers, onions, zukini, long beans, baby corn, onion spring, and masrum. Consequently, the average number of requests per 1000 hotel and restaurant guests in a month were: 518, 334, 1,337, 2,889, 99, 595, 287, 781, 684, $249,413,260,57,21,720,119,263,4,54,19,126,39 \mathrm{~kg}$, except spinach in bunches and masrum in packets. Average request values per 1000 hotel and restaurant guests in a month are: 15.22, 4.53, 27.32, 22.96,3.09, 13.91, 17.76, 3.09, 10.42, 4.80, 2.82, 7.93, 0.34, 1.61, 5.60, 1.87, 3.92, 0.17, 0.34, 0.27, 1,18, 0.29 million Rupiah.

Fresh fruit, including 18 types, namely: sweet orange, lime / lemon, watermelon, melon, apple, pineapple, papaya, mango, banana, peer, grape, strawberry, salak, avocado, dragon, blueberry, kiwi, and charry. Consequently, the average numbers of requests per 1000 hotel and restaurant guests in a month were: 14,166, 4,020, 18,701, 50,068, 4,247, 8,436, 5,068, $45,084,26,429,1,264,8,266,2,205,1,679,875,11,086,2,516,8,353$, and $335 \mathrm{~kg}$. The 
average value of requests per 1000 hotel and restaurant guests in a month are: 14.21, 6.27, $32.98,9.68,3.27,20.73,33.75,5.21,12.62,0.63,0.36,4.25,0.39,3.06,2.40,1.17,2.81$, and 0.16 million Rupiah.

Fresh fish includes 17 types of marine and freshwater fish, namely: shrimp, squid, mahi mahi, grouper, baronang, tuna, snapper, salmon, crab, snapper, scallop, mackerel, shellfish, tilapia, pomfret, gouramy and catfish. . Respectively, the average number of requests was: $904,646,659,38,198,505,365,65,24,358,442,25,55,78,3,19$, and $28 \mathrm{~kg}$ per 1000 guests hotels and restaurants in a month. The average demand values are: $87.66,53.49$, $43.16,1.15,4.96,35.70,27.38,3.17,1.83,25,40,22,81,1.79,3.57,3.43,0.10,0.48$, and 0.84 million Rupiah.

The types of fresh meat requested by hotels and restaurants can be divided into 11 types, namely: beef, chicken, beef fillet, chicken fillet, lamb, duck, chicken leg, chicken brest, and beef bone. Consecutively, the average number of chicken wings, beef mince, demand was: 984, 2,140, 38, 148, 85, 190, 294, 130, 376, 39, and $5 \mathrm{~kg}$ per 1000 hotel and restaurant guests in a month. The average demand values are: 124.26, 62.81, 4.29, 8.86, 22.56, 31.27, 11.59, 7.17, 7.90, 3.12, and 0, 29 million Rupiah.

Processed food ingredients requested by hotels and restaurants include 12 types, namely: ready-to-fry potatoes, salami, beef ham, chicken ham, beef bacon, beef meat ball, beef Sausage, chicken sausage, ice cream, strings, cococrunch, and honey starch. Respectively, the average number of requests was: $21,17,17,4,23,15,6,14,89,17$, 37 , and $19 \mathrm{~kg}$ per 1000 hotel and restaurant guests in a month. The average demand values are: $0.73,2.13,1.99,0.22,3.47,1.05,0.16,1.02,3.55,0.63,1,45$, and 0.74 million rupiah.

Hotel and restaurant requests for other foodstuffs cover 17 types, namely white rice, sugar, ground coffee, cooking oil, bottled water, tea bags, liquid milk, coffee beans, brown sugar, powdered milk, brown rice, salt, butter, eggs, flour, noodles, and sphaggeti. Respectively, the average number of requests was: $5,960,2,172,275,3,275,2,480,47$, 298, 132, 411, 89, 73, 3, 27, 115, 84, 101, and $33 \mathrm{Kg}$ per 1000 guests hotels and restaurants in a month. The average demand values are: 75.26, 28.75, 33.62, 49.72, 89.52, $1.19,3.91,27.84,15.87,6.55,1,65,0.03,2.69,5.23,15.57,0.51$, and 0.83 million Rupiah.

Strategic issues of strengthening the business linkages in the tourism sector and local agricultural and processing businesses in West Lombok district: The number of visitors, business scale, and the decisions of the Chef and the Procurement Department affect the demand for hotels and restaurants for food; the competitiveness of local food products is a prerequisite for realizing it. Potential for strengthening local business and tourism links; and hotel and restaurant suppliers bear a relatively large burden of operating capital requirements because partner hotels and restaurants generally apply a monthly payment system.

Potential policy directions for strengthening the business linkages in the tourism sector and agricultural businesses and managing local food ingredients are: advocacy for the use of local food ingredients in hotel and restaurant food menus, increasing the number of tourist visits, increasing the competitiveness of local products in markets and buying centers for hotels and restaurants. and suppliers, and access to finance for local producers and suppliers. Among the potential program activities for this purpose are: developing linkages between banks, suppliers and hotels.

\section{REFERENCES}

1. Aref, P. Redzun, M., \& Gill, S. S. (2010) Dimensions of Community Capacity Building A review of its Implications in Tourism Development Journal of American Science, Vol.6(1), 172-180.

2. Arizona State University. (2010). Tourism resources assessment for Maricopa, Arizona. ASU College of Public Programs.

3. Coccorese, P, \& Pellecchia, A. (2006). Local tourism features in Jtaly: a binomial logit analysis. Tourism Economics 12(1): 565-583. 
4. Crouch, G. I, \& Ritchie, B. R. (1999). Tourism, Competitiveness and Societal Prosperity Journal of Busines Research Vo.44, Issue 3, March 1999, 137-152.

5. Denicolai, S., Cioccarelli, G., \& Zucchella, A. (2010). Resource-based local development and networked core competencies for tourism excellences. Tourism Management 31(2): 260- 266 Tourism.

6. Dredge, D. (2006). Policy Networks and Local Organization of Tourism. Management 27 (2), 269-280.

7. Haxon, P. (2015). A Review of Effective Policies for Tourism Growth. OECD Tourism Working Paper 2015/1.

8. Herrero-Prieto, L., \& Gomez-Vega, M. (2017). Cultural resources as a factor in cultural tourism attraction: technical efficiency estimation of regional destinations in Spain Tourism Economics 23(2): 260-280. International Trade Centre. (2010). Inclusive Tourism: Linking Agriculure to Tourism Market. Geneva: ITC.

9. Kotler, P. (1988). Marketing Management, sixth edition. New Jersey: Prentice Hall.

10. Laesser, C., \& Crouch, G. (2006). Segmenting markets by travel expenditure patterns: the case of international visitors to Australia. Journal of Travel Research 44(4): 397-406.

11. Mathieson, A., \& Wall, G. (1982). Tourism: Economic, physical and social impacts. London: Longman.

12. OECD. (2012). Food and the Tourism Experience: The OECD-Korea Workshop, OECD Studies on Tourism,, OECD Publishing.

13. OECD (2014). Tourism and the Creative Economy, OECD Studies on Tourism.http://dx.doi.org/10.1787/9789264207875-en: OECD Publishing.

14. Privitera, D., Nedelcu, A., \& Nicula, V. (2018). Gatronomic and Food Tourism as an Economic Local Resources: Case Studies from Romania and Italy. Geo Jurnal of Tourism and Geosites Year XL No. I vol 21 May 2018, 143-157.

15. Scuderi, R. (2018). Local Resources for Tourism - from Impact to Growth. Tourism Economics 2018, Vol. 24(3) 294-296.

16. Shafer, R. (1989). Community Economics, Economic Structure and Change in Smaller Communities. Ames, lowa: lowa State University Press.

17. UNESCO. (2013). Creative Economy Report: Widening Local Development. New York and Paris: UNDP-UNESCO.

18. World Tourism Organization. (2004). Indicators of Sustainable Development for Tourism Destinations: A Guidebook. Madrid, Spain: WTO. 